\title{
Selection of alfalfa genotypes for resistance to the foliar pathogen Curvularia geniculata
}

\author{
MARIANA R. ÁVILA ${ }^{1}$, MIGUEL DALL'AGNOL ${ }^{1}$, JOSÉ A. MARTINELLI', \\ GERARDA B.P. DA SILVA ${ }^{2}$, CAROLINA BREMM ${ }^{3}$ and TAMYRIS NUNES ${ }^{1}$ \\ ${ }^{1}$ Deapartment of Forage Plants and Agrometeorology, Federal University of Rio Grande \\ do Sul, Av. Bento Gonçalves, 7712, 91501-970 Porto Alegre, RS, Brazil \\ ${ }^{2}$ Department of Plant Pathology, Federal University of Rio Grande do Sul, Av. \\ Bento Gonçalves, 7712, 91501-970 Porto Alegre, RS, Brazil \\ ${ }^{3}$ State Foundation for Agricultural Research, Rua Gonçalves Dias, 570, 90130-060 Porto Alegre, RS, Brazil
}

Manuscript received on January 10, 2017; accepted for publication on March 27, 2017

\begin{abstract}
Foliar diseases impose severe restrictions on the persistence and productivity of Medicago sativa, both of which may be increased by developing disease resistant and more competitive genotypes that can improve pasture quality. We found Curvularia geniculata as the principal alfalfa foliar pathogen in the Brazilian state of Rio Grande do Sul (RS). Growth chamber experiments evaluated the resistance of alfalfa genotypes ' $\mathrm{E}_{1} \mathrm{C}_{4}$, ' 'CPPSul', 'ABT 805' and 'CUF-101' to C. geniculata as compared the control 'Crioula' genotype. These genotypes were also evaluated in field trials at a sea level site in Eldorado do Sul in central RS and at two sites $200 \mathrm{~m}$ above sea level, one in Bagé municipality in south west RS and the other at a farm near the town of Alto Feliz in north east RS. Plants were spray-inoculated with $1.6 \times 10^{6} \mathrm{ml}^{-1}$ of $C$. geniculata spores and visually evaluated for leaf damage 14 days later. The $C$. geniculata infection rates varied from zero to $100 \%$. Alfalfa persistence and forage mean dry mass (DM) production at the Eldorado site were measured during different seasons from November 2013 to January 2015 by calculating the incidence of invasive plants and morphologically separating leaves from stems and calculating both leaf and stem DM. Data were analysed using mixed statistical models. The best results for persistence and forage DM were shown by the 'CPPSul' genotypes ( $\left.\mathrm{DM}=16,600 \mathrm{~kg} \mathrm{ha}^{-1}\right)$ and 'Crioula' $\left(\mathrm{DM}=15,750 \mathrm{~kg} \mathrm{ha}^{-1}\right)$. These two genotypes will be used for subsequent investigations and selection cycles.
\end{abstract}

Key words: lucerne, invasive plants, foliar pathogen, forage legumes.

\section{INTRODUCTION}

Alfalfa (Medicago sativa L. ssp. sativa), also known as lucerne, is a high quality persistent legume cultivated as a monoculture or intercropped with grasses for use as green forage, silage or hay

Correspondence to: Mariana Rockenbach de Ávila

E-mail: marianaravila@gmail.com
(Jung et al. 1997). Although alfalfa is considered the 'queen of forages' and one of the most globally cultivated forage legumes (Michaud et al. 1988), it has some specific requirements before it can reach high productivity and persistence. Since alfalfa is susceptible to more than 70 different types of fungi, 30 of which are considered limiting for its growth 
and productivity (Thal and Campbell 1987), the low persistence of alfalfa could partly be linked to foliar diseases (Beuselinck et al. 1994, Barnes 1991, Sheaffer et al. 1992). However, alfalfa growth can also be limited by complex interactions between one or more diseases and other constraints (Gossen 1994), such as fertility and soil drainage (Smith et al. 1989) or competition from invasive plants (Buhler et al. 1998).

Plant diseases have been estimated to be responsible for a ten percent loss in global animal production, mainly due to limiting the total energy available to plants rather than killing them (Chakraborty et al. 1996). Losses in forage yield could be reduced by controlling foliar diseases (Gray and Fernandez 1987), the investigation of which is one of the more important aspects in the selection and development of plant genotypes (Pozza and Souza 1994). Genetic resistance is the most practical and widely used disease control strategy (Skipp and Hampton 1996) because it is not only the most economical and efficient mechanism for such control but is also environmentally friendly.

The hyphomycete fungus Curvularia geniculata is a facultative foliar pathogen for many plant species: including Kentucky bluegrass (Poa pratensis) (Rogerson 1956), grasses in Florida (Bailey and Muchovej 2001), Bermuda grass in Mississippi (Pratt 2005), rice in China (Jin 1989) and cereals in Uzbekistan (Khasanov et al. 1990). Alfalfa fungal foliar pathogens, including $C$. geniculata, cause damage by reducing the general performance of the plant as a forage by affecting factors such as the life cycle and population density of the plant and hence forage quality (Elgin et al. 1988). Pathogens also increase production costs by using some of the inputs destined for the plants and sometimes necessitating the frequent replanting of alfalfa problem areas. (Elgin et al. 1988). In Florida, for example, Curvularia species have been found colonizing the majority of grass samples, including those from apparently healthy plants, and C. geniculata has been shown to compete aggressively for plant tissue and sporulate most rapidly at $30^{\circ} \mathrm{C}$, a temperature commonly attained in southern Brazil. Germination and optimal growth of C. geniculata occurs above $15{ }^{\circ} \mathrm{C}$ (Hodges 1972) and when high temperatures are associated with heavy rains (Nelson 1964). Chlorosis caused by this pathogen begins at the tips of leaves and proceeds downwards to the leaf sheath, with chlorotic infected leaves becoming progressively necrotic so that when conditions are optimal the fungus can colonize the leaf sheath.

Brazil is the world's largest producer of beef cattle (USDA 2016), having risen from second place in 2012 (USDA 2012), cattle mainly being pasture reared on about 197 million hectares (FAO 2010). However, Brazilian producers have been compelled to improve their productivity (Costa 2010) due to increased land prices (Anualpec 2010) and the increased global demand for food (FAO 2011, Foresight 2011). Even at current levels of productivity there is still a need to incorporate more productive forage genotypes into pasture production systems, but it is important that intensification of such systems should be guided by the efficient use of genetic resources to minimize the risk of economic losses (Barcellos et al. 2008).

Rio Grande do Sul (RS), the southernmost Brazilian state, is a major agricultural producer with the sixth largest cattle herd in Brazil of about 14.5 million head with an annual aggregate value of beef production in the region of US\$ 900 million, about US\$ 100 million of which is for export (SDPI 2013). The cattle are mainly reared on 8 million hectares of natural pastures within the Pampa biome (FEE 2015). This biome consists mainly of grasslands with some shrubs and trees and occupies about 17.6 million hectares situated between latitudes $28^{\circ} 00^{\prime} \mathrm{S}$ and $34^{\circ} 00^{\prime} \mathrm{S}$ and longitudes $49^{\circ}$ $30^{\prime} \mathrm{W}$ and $58^{\circ} 00^{\prime} \mathrm{W}$ in the South Temperate Zone, which has subtropical and temperate climates with four distinct seasons (Roesch et al. 2009). The 
climate in the Brazilian Pampa is unique in that it allows grazing throughout the year (Williams et al. 1968). However, the quality of pastures can limit productivity and this may be improved by adding alfalfa may be increased by developing more competitive, disease-resistant and persistent alfalfa genotypes (Bouton 2012).

Many pests and diseases affect alfalfa in Brazil, but the damage caused by such attacks has been largely undocumented (Porto 1988) and few attempts have been made to investigate variation within or between alfalfa genotypes in their response to pathogen attack. However, such studies are crucial for understanding the role of fungi in plant community dynamics (Burdon 1980).

Globally, little is known regarding the interaction between foliar diseases and individual alfalfa genotypes and how these factors relate to forage production. We investigated these factors in Rio Grande do Sul as a model ranchers in other parts of the world with similar geographical and climatic conditions. Our objectives were: 1 . to identify the foliar diseases affecting selected alfalfa genotypes in Rio Grande do Sul, 2. evaluate the genetic resistance of alfalfa genotypes to the main foliar pathogen, Curvularia geniculata, and 3. estimate alfalfa persistence and forage production under field conditions.

\section{MATERIALS AND METHODS}

ISOLATION AND PATHOGENICITY OF C. geniculata

Isolation and pathogenicity testing of Curvularia geniculata was undertaken during mid-June to mid-September (winter) and mid-September to mid-December (spring) of 2013. Alfalfa (Medicago sativa L. cv Crioula) leaves exhibiting lesions were collected from four farms in two different geographic regions of the Brazilian state of Rio Grande do Sul (RS): the Campanha, a region of pampa with an elevation of about 200 meter above sea level in the south west of the state (farms at $31^{\circ} 19^{\prime} 43^{\prime \prime} \mathrm{S} 54^{\circ} 6^{\prime} 26^{\prime \prime} \mathrm{W}$ and $30^{\circ} 52^{\prime} 23^{\prime \prime} \mathrm{S} 54^{\circ} 40^{\prime}$ $\left.36^{\prime \prime} \mathrm{W}\right)$ and the Serra region, a mountainous region at about 700 meter above sea level in the north of the state (farms at $29^{\circ} 27^{\prime} 5^{\prime \prime} \mathrm{S} 51^{\circ} 18^{\prime} 24^{\prime \prime} \mathrm{W}$ and $\left.29^{\circ} 23^{\prime} 56^{\prime \prime} \mathrm{S} 51^{\circ} 15^{\prime} 15^{\prime \prime} \mathrm{W}\right)$.

The leaves were transported to our laboratory in Porto Alegre within $24 \mathrm{~h}$, being maintained at 20-22 ${ }^{\circ} \mathrm{C}$ during the journey before being examined for fungal pathogens. We identified the principal alfalfa pathogens associated with leaf lesions using microscopy to determine fungal morphology and conidial dimensions (Barnett and Hunter 1999) along with standard mycological methods (Thirumalachar, Narasimhan 1953), the lesions mostly being caused by the fungi Curvularia geniculata and Alternaria alternata. To obtain pure cultures of $C$. geniculata and A. alternata from the lesioned leaves, they were disinfestated for 30 seconds in $70 \% \mathrm{v} / \mathrm{v}$ alcohol followed by 1 minute in $1 \% \mathrm{w} / \mathrm{v}$ sodium hypochlorite, washed in sterile distilled water and placed in a moist chamber at $>95 \%$ rh for 48 h., after which a small portion of cotton mycelium was transferred to plates containing Potato Dextrose Agar (PDA) (Difco, Michigan, USA) which were incubated at $25{ }^{\circ} \mathrm{C}$ for 5 days. The directly isolated cultures were transferred to PDA slopes, which were incubated appropriately and then stored at $25^{\circ} \mathrm{C}$ until needed.

\section{GROWTH CHAMBER PATHOGENICITY TESTING}

To investigate $C$. geniculata and A. alternata isolates for pathogenicity towards alfalfa genotype 'Crioula', we used PDA slope, incubated at $25{ }^{\circ} \mathrm{C}$ for 7 days, to prepare a suspension of conidia (1.6 $\mathrm{x} 10^{6} \mathrm{ml}^{-1}$ ) for each fungal isolate, the suspensions being used to inoculate 30 plants 30 days old with C. geniculata and 30 with A. alternata, with 10 uninoculated plants serving as controls for each fungus. After inoculation, the plants were kept in a growth chamber at $>95 \% \mathrm{rh}$ at $22{ }^{\circ} \mathrm{C}$ to 25 ${ }^{\circ} \mathrm{C}$ for 24 hours and then at $>95 \%$ rh at a mean 
temperature of $25{ }^{\circ} \mathrm{C}$ until the appearance of symptoms, the presence of which was taken as confirmation of Koch's postulates for the isolate under investigation. Both isolates were pathogenic, but we decided to use only $C$. geniculata for the studies described in this paper because this fungus was more frequent and more aggressive to alfalfa growing in Rio Grande do Sul.

In June 2014 we deposited reference samples of both C. geniculata and A. alternata isolated from all the regions in a plant pathology reference culture collection (Instituto Biológico, São Paulo, Brasil), where their identities were confirmed as C. geniculata Tracy and Earle and Alternaria alternata (Fr.) Keissler using a rapid DNA isolation procedure (Doyle and Doyle 1987) and standard mycological methods (Sung et al. 2007, Liu et al. 1999; White et al. 1990). The MMBF accession numbers for the $C$. geniculata isolate from the Serra region was MMBF 12/14 whilst that from the Campanha was MMBF 13/14.

\section{GROWTH CHAMBER RESISTANCE SELECTION}

Laboratory selection for plant resistance to $C$. geniculata isolates was carried out from January 2014 to April 2015 in a growth chamber at the Department of Plant Pathology and Department of Forage Plants and Agrometeorology, Agronomy Faculty, Federal University of Rio Grande do Sul (UFRGS), Porto Alegre, Rio Grande do Sul State, Brazil.

Single isolate inocula were prepared from virulent isolates of $C$. geniculata from the Serra and the Campanha by transferring colonies of individual isolates to PDA plates and incubated them at $25{ }^{\circ} \mathrm{C}$ for 10 days to achieve maximum growth and sporulation (Hodges 1972), after which they were washed twice in $5 \mathrm{ml}$ of sterile distilled water containing $0.01 \mathrm{ml} \mathrm{ml}^{-1}$ of Tween-20 (Synth, São Paulo, Brazil) to produce conidial suspensions which were counted in a Neubauer chamber and appropriately diluted to produce a final total conidial count of $1.6 \times 10^{6} \mathrm{ml}^{-1}$.

We evaluated five alfalfa genotypes for resistance to the fungal isolates: the Brazilian largest commercial cultivar 'Crioula' (used as control), ' $\mathrm{E}_{1} \mathrm{C}_{4}$ ' and 'CPPSul' (both grazing tolerant genotypes) plus the US cultivars 'ABT805' (grazing type, non dormant) and 'CUF-101' (hay-type, non dormant). Seeds of each genotype were obtained from South Brazil for 'Crioula', ' $\mathrm{E}_{1} \mathrm{C}_{4}$ ' and CPPSul and from United States of America for 'ABT-805' and 'CUF-101'. All seeds were disinfested for 30 seconds in $70 \% \mathrm{v} / \mathrm{v}$ alcohol followed by 1 minute in $1 \% \mathrm{w} / \mathrm{v}$ sodium hypochlorite, washed in sterile distilled water, mechanically scarified with sand paper to break dormancy and then placed on water-agar plates in a growth chamber at $25{ }^{\circ} \mathrm{C}$ until the radicles of the seedlings were about $10 \mathrm{~mm}$ long, after which they were planted into styrofoam trays filled with autoclaved commercial substrate (composition: sphagnum peat, expanded vermiculite, dolomitic limestone, agricultural gypsum, and NPK fertilizer. Density $101 \mathrm{~kg} \mathrm{~m}^{-3}$ ).

On the 12 of March 2014, when the plants were 30 days old and at stage vegetative with the $2^{\text {nd }}-3^{\text {rd }}$ trifoliate, the leaves of 300 replicate plants were inoculated with a hand sprayer containing one of the conidial suspensions, this being repeated for each fungal isolate. After inoculation, the plants were kept in a growth chamber at $>95 \%$ rh and $25{ }^{\circ} \mathrm{C}$ for 24 hours and then at a mean daily $85 \%$ rh and temperature of $25^{\circ} \mathrm{C}$ until the appearance of symptoms. The presence or absence of $C$. geniculata was periodically assessed microscopically and the plants evaluated for disease severity 14 days after inoculation.

The experiment was arranged in a completely randomised design with 300 replicates, with each seedling being considered one replicate of each population. The percentage of leaf area damaged was visually estimated for the 6 to 9 leaflets on 
each seedling, 25 plants showing more than 30 $\%$ damage comprising the susceptible genotype group, 25 plants showing between 0.1 to $1 \%$ the resistant genotype group and 25 plants showing no symptoms the highly resistant or immune genotype group. Seed from the three groups will be used for future crosses and their F1 seeds tested.

\section{FIELD EVALUATION OF FORAGE YIELD AND COMPETITION}

The evaluation of forage yield and competition in the field was carried out in the Central Depression Region of Rio Grande do Sul at the Agricultural Experimental Station (Estação Experimental Agronômica, EEA), UFRGS, Eldorado do Sul $\left(30^{\circ} 05^{\prime} \mathrm{S}, 51^{\circ} 39^{\prime} \mathrm{W}\right)$, this region having a humid subtropical climate characterised by hot and usually humid summers with mild to cool winters (Köppen climate classification Cfa) (Bergamaschi et al. 2003). The soil is classified as a Typic Paleudult (USDA 1999) with $15 \%$ clay. The climate is subtropical humid with hot summers and some winter frosts (Köppen classification "Cfa"). The mean annual temperature is $19.5{ }^{\circ} \mathrm{C}$ and total rainfall $1,335 \mathrm{~mm}$, the monthly temperature average and precipitation being shown in Figure 1. Meteorological data during experimental period was acquired from the Brazilian National Institute of Meteorology (INMET).

On the 29th of June 2013 we disinfested seeds of the five alfalfa genotypes cited above, inoculated them with the nitrogen-fixing bacteria Rhizobium meliloti strain SEMIA 116 (kindly provided by FEPAGRO, Porto Alegre, Brazil) and then pelletised the seeds with $\mathrm{CaCO}_{3}$ before manually sowing them at an equivalent density of $20 \mathrm{~kg} \mathrm{ha}^{-1}$.

The soil had been analysed 60 days before application of fertilizer and, based on this analysis, dolomite liming was performed in April 2013 to raise base saturation to $85 \%$. A cover fertilization was carried out with superphosphate $(100 \mathrm{~kg}$ ha$\left.{ }^{1}\right)$ and potassium chloride $\left(100 \mathrm{~kg} \mathrm{ha}^{-1}\right)$, with subsequent yearly application of superphosphate $\left(100 \mathrm{~kg} \mathrm{ha}^{-1}\right)$ and three-monthly application of $\mathrm{KCl}$ $\left(50 \mathrm{~kg} \mathrm{ha}^{-1}\right)\left(120 \mathrm{~kg} \mathrm{ha} /\right.$ year of $\left.\mathrm{K}_{2} \mathrm{O}\right)$. Irrigation was provided twice in August and September.

We used a completely randomized block statistical design with three replicates. The normal width between alfalfa lines is $20 \mathrm{~cm}$ but we used $50 \mathrm{~cm}$ to facilitate the evaluations and harvesting, being each line one alfalfa genotype. In our experiments, where cuts were made each block consisted of $1 \mathrm{~m}$ long lines, $50 \mathrm{~cm}$ between lines and $50 \mathrm{~cm}$ borders with $1 \mathrm{~m}$ between blocks. The forage production values were converted to $\mathrm{kg} \mathrm{ha}^{-1}$ based on a standard width between lines of $20 \mathrm{~cm}$.

Cuts and evaluations were made from spring 2013 (November) to summer 2015 (January), as follows: two cuts in spring $2013\left(22^{\text {nd }}\right.$ November and $10^{\text {th }}$ December $)$, two in summer $2014\left(20^{\text {th }}\right.$ January and $10^{\text {th }}$ February), one in autumn 2014 (25 April), two in winter 2014 (14 $4^{\text {th }}$ June and $04^{\text {th }}$ September) two in spring $2014\left(14^{\text {th }}\right.$ November and $08^{\text {th }}$ December) and one in summer $2015\left(14^{\text {th }}\right.$ January).

Ten cuts were made, with an average sward height of $45 \mathrm{~cm}$ and leaving $10 \mathrm{~cm}$ of residue to accelerate regrowth and increase the number of new shoots. Along with the mass evaluations and sward height we also evaluated the occurrence of invasive plants on all lines using a visual scale of 0 (no invasive plants in the line) to 10 (invasive plants throughout the line), which produced an invasive plant index that was used just before each cut.

Material from each cut was separated into leaves and stems and dried in a forced-air oven at $60{ }^{\circ} \mathrm{C}$ for 72 hours before weighing and determining stem dry mass $\left(\mathrm{kg} \mathrm{ha}^{-1}\right)$ and leaf dry mass $\left(\mathrm{kg} \mathrm{ha}^{-1}\right)$ and total dry mass $\left(\mathrm{kg} \mathrm{ha}^{-1}\right)$, the latter being the sum of stem dry mass plus leaf dry mass. 


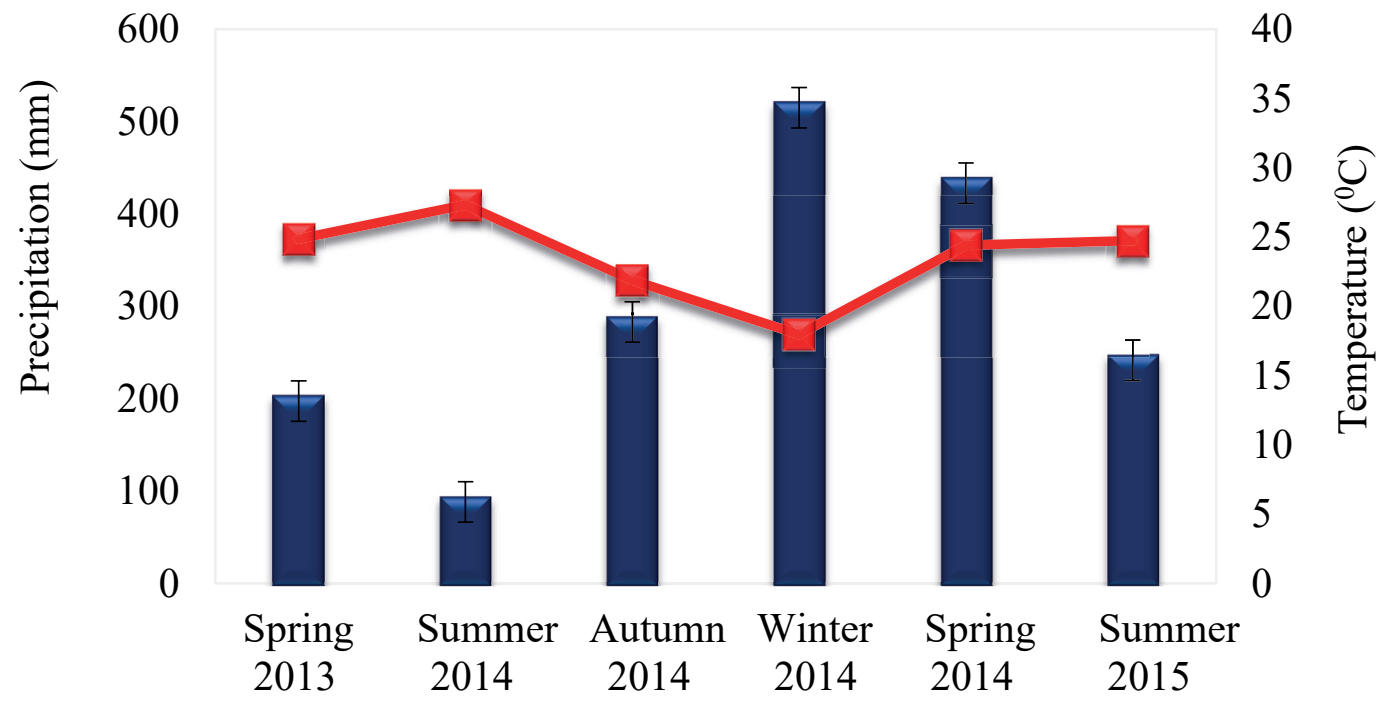

Figure 1 - Mean seasonal temperature and precipitation during November 2013 to January of 2015. Agricultural Experimental Station, Federal University of Rio Grande do Sul, Eldorado do Sul, Brazil. Data from the Brazilian National Meteorology Institute (Instituto Nacional de Meteorologia, INMET).

FIELD EVALUATION OF ALFALFA RESISTANCE TO C. GENICULATA

Evaluation of resistance to $C$. geniculata in the field was undertaken in the following three physiographic regions of Rio Grande do Sul:

1) The Southern Brazilian Center for Livestock Research (Embrapa Pecuária Sul, CPPSUL) $\left(31^{\circ} 20^{\prime} \mathrm{S}, 5^{\circ} 06^{\prime} \mathrm{W}\right)$, in Bagé Municipality, where the soil is a Luvisols (EMBRAPA 2013) and the climate is cold subtropical (hot summers and frequent frosts in winter) with a mean annual temperature of $18{ }^{\circ} \mathrm{C}$ and a mean total annual rainfall of $1465 \mathrm{~mm}$;

2) EEA Eldorado do Sul ( $\left.30^{\circ} 05^{\prime} \mathrm{S}, 51^{\circ} 39^{\prime} \mathrm{W}\right)$, which soil and climate are classified as above;

3) A farm near the town of Alto Feliz (29 23' $56 " \mathrm{~S}$ and $\left.51^{\circ} 15,15^{\prime \prime} \mathrm{W}\right)$, where the soil is a Neosol Leptosols (Streck et al. 2008) and the climate is subtropical humid (hot summers and humid winters) with a mean annual temperature of $17{ }^{\circ} \mathrm{C}$ and a mean total annual rainfall of $1,603 \mathrm{~mm}$. The alfalfa genotypes Crioula, $\mathrm{E}_{1} \mathrm{C}_{4}$, CPPSul, ABT-805 and CUF-101, the C. geniculata isolate and experimental design at CPPSUL and EEA were the same as those used for the forage yield and competition experiments described above. In the second week of October 2014 (spring), seven days after a standardization cut was made, when the alfalfa plants were $25 \mathrm{~cm}$ tall, we inoculated the each plot of genotypes with a $C$. geniculata conidial suspension ( $1.6 \mathrm{x}$ $\left.10^{6} \mathrm{ml}^{-1}\right)$. We covered each inoculated plot with plastic film to produce a moist environment and facilitate conidia germination. Evaluation was made 15 days after inoculating the four central plants of each plot. The percentage of lesioned leaf area of each inoculated leaflet was visually estimated on a $0 \%$ to $100 \%$ scale. In Alto Feliz, the main region using alfalfa, the experimental area consisted of a $3 \times 3$ meter plot of the 'Crioula' cultivar because it was the one already cultivated in the farm.

\section{STATISTICAL ANALYSIS}

Statistical analysis was done using mixed models (SAS Inst. Inc., Cary, NC) with fixed effects for genotypes, seasons (years) and interaction between 
genotypes and seasons (year), and random effects for block, characterizing the observation with a temporal correlation. The evaluation periods were considered to be repeated measures, where each period represented the measurement of the same experimental unit under a different condition. Compound symmetry (CS) was the covariance matrix that best fit the data. The covariance matrices were compared by the Akaike's information criterion (AIC). The variable resistance model included the fixed effects of region, genotype and interaction between regions and genotypes. The plant (line) was considered a random effect. When statistical differences were detected in the analysis of variance at $\mathrm{P}<0.05$, means were compared by the Tukey significant difference (HSD) test at 5\% of significant level. The variables were tested for a normal distribution using the Shapiro-Wilk test at $\mathrm{P}>0.05$ and the variable invasive plants did not fit the normal distribution. Thus, a generalized linear mixed model was used to study the invasive plants, considering the same effects included in the mixed models. Correlation analysis between TDM and invasive plants were also conducted.

\section{RESULTS}

The mean seasonal temperature and precipitation from November 2013 to January of 2015 are presented in Figure 1. Over the two years of the study the average spring and summer temperatures ranged from $25{ }^{\circ} \mathrm{C}$ to $28{ }^{\circ} \mathrm{C}$, while the lowest temperature, $20{ }^{\circ} \mathrm{C}$, occurred in winter 2014 . The highest precipitation $(550 \mathrm{~mm})$ occurred in 2014 , with reasonable amounts also occurring in autumn (300 mm) and spring $(450 \mathrm{~mm})$. In the summer of 2015 precipitation was about $250 \mathrm{~mm}$, more than twice as much as the $100 \mathrm{~mm}$ which fell in 2013.

The alfalfa leaf damage caused by $C$. geniculata under controlled conditions in a growth chamber and in field trials is shown in Figure 2. In the growth chamber experiments, Crioula' and
' $\mathrm{E}_{1} \mathrm{C}_{4}$ ' showed less disease on leaves than the other genotypes, although ' $\mathrm{E}_{1} \mathrm{C}_{4}$ ' was statistically similar to 'CPPSul', 'ABT805' and 'CUF-101'. In the CPPSUL field trials, 'Crioula' and ' $\mathrm{E}_{1} \mathrm{C}_{4}$ ' were the most resistant genotypes, both showing statistically less disease than the 'CPPSul', 'ABT805' and 'CUF101 ' genotypes. In the field trials, 'Crioula' was the most resistant genotype, differing statistically from all the other genotypes. Genotype 'CUF-101' was the most susceptible genotype at the EEA site, with leaf disease severity reaching $35 \%$. In both the growth chamber experiments and the CPPSul field trials the 'CUF-101', 'CPPSul' and 'ABT805' genotypes all showed equal susceptibility.

The alfalfa leaf, stem and total dry matter yield $\left(\mathrm{kg} \mathrm{ha}^{-1}\right)$ for spring 2013, summer, autumn, winter and spring 2014, and summer 2015 in a field experiment conducted at the Agricultural Experimental Station are given in Table I. For leaf dry mass, there was no difference between the genotypes during the spring of 2013 and autumn of 2014. The 'Crioula' and 'CPPSul' genotypes showed the highest of leaf dry mass yields for summer and spring 2014. These genotypes also showed the highest leaf dry mass values for winter 2014 and summer 2015, although they were not statistically different from ' $\mathrm{E}_{1} \mathrm{C}_{4}$ ' during winter 2014 and from ' $\mathrm{E}_{1} \mathrm{C}_{4}$ ' and 'ABT-805' during summer 2015. For stem dry mass production, there was no difference between the genotypes during spring 2013 or summer, autumn and spring 2014. In winter 2014, 'CPPSul', 'Crioula' and ' $\mathrm{E}_{1} \mathrm{C}_{4}$ 'showed the highest yields, while for summer 2015, 'CPPSul', 'Crioula', ' $\mathrm{E}_{1} \mathrm{C}_{4}$ ' and 'ABT805 ' were equally high yielding. The total (leaf + stem) dry mass showed no difference between the genotypes for the spring 2013 and autumn 2014 seasons only. Overall, 'Crioula' and 'CPPSul' showed the highest yields in all seasons, although they were statistically similar to ' $\mathrm{E}_{1} \mathrm{C}_{4}$ ' for winter 2014 and ' $\mathrm{E}_{1} \mathrm{C}_{4}$ ' and 'ABT-805' for summer 2015. 
The relationship between invasive plants and total dry matter of alfalfa genotypes in the field at the Agricultural Experimental Station is shown in Figure 3. There was a negative linear correlation between invasive plants and total dry matter $\left(\mathrm{R}^{2}=\right.$ $0.8244, y=-0.0829 x+31.745)$. The 'Crioula' and 'CPPSul' genotypes showed the highest total dry matter yields and the lowest percentage of invasive plants. Compared to 'Crioula' and 'CPPSul', the 'CUF-101', ' $\mathrm{E}_{1} \mathrm{C}_{4}$ ' and ABT805' genotypes showed relatively lower yields and a higher percentage of invasive plants.

\section{DISCUSSION}

ISOLATION AND PATHOGENICITY OF C. geniculata

During the selection and evaluation of genotypes for resistance, the first symptoms seen on the leaves of the genotypes were yellowish spots that quickly turned brown, indicating dead tissue, and became characteristic $\mathrm{v}$-shaped lesions radiating from the leaf vein. These symptoms appeared about four days after inoculation in the growth chamber and six days in the field, with many leaves being already partially dead two weeks after inoculation. Damage was more extensive in younger leaves than in older ones. Once the petiole was infected, necrosis soon lead to the death of the whole leaf, and when severe infection occurred the whole plant appeared to be burned and the yield was affected.

We found that the North American cultivars 'ABT-805' and 'CUF-101' had, as expected, a higher incidence of leaf lesions in the field ( $p$ $<0.001$ ) and were more susceptible to Curvularia spot $(\mathrm{p}<0.001)$, because they were not adapted to the local conditions, whereas the Brazilian genotypes were adapted and hence more resistant.

There is little published information about the occurrence of C. geniculata in Brazil or its effects in regard to Brazilian pastures. However, southern Brazil does have a hot and humid climate favourable to the spread of this pathogen, which mainly occurs in late spring and early summer, the period preceding the critical stage for the persistence of alfalfa. Furthermore, it has been reported that the severity of Curvularia spot is considerably increased when high temperatures occur after the rainy season (Falloon 1976, Kim 2000). Leaf lesions caused by diseases in periods of unfavorable climate for the growth of forages contribute not only to decreased production but also to debility and death of the plant (Nelson and Campbell 1993). It is possible that $C$. geniculata, associated with other pathogens, can reduce both the productivity and persistence of alfalfa in pastures in Rio Grande do Sul. With the expansion of pastures and the intensification of their activities in recent years, many forage diseases have started to significantly impact alfalfa, causing losses of forage yield and quality (Mallmann et al. 2013).

\section{GROWTH CHAMBER AND FIELD EVALUATION OF ALFALFA RESISTANCE TO C. geniculata}

In the growth chamber evaluations, 'Crioula' presented the highest number of immune plants. The genotypes selected for their susceptibility could be distinguished from the genotypes selected for their resistance $(p<0.01)$, (Figure $2 a, 2 b)$. We found that 'CUF-101' showed the highest susceptibility of all the genotypes evaluated, with $35 \%$ disease severity at the EEA field site and $40 \%$ disease severity in the growth chamber experiments (Figure 2a, 2b). At the CPPSUL and EEA field sites the 'Crioula' and ' $\mathrm{E}_{1} \mathrm{C}_{4}$ ' genotypes presented smaller lesions and were more resistant to, while in the growth chamber experiments 'Crioula' was $15 \%$ more resistant and ' $\mathrm{E}_{1} \mathrm{C}_{4}$ ' $20 \%$ more resistant. In the growth chamber experiments, there was no difference between the genotypes 'ABT805' (38\% disease severity) and 'CUF-101' (40\% disease severity).

Despite the fact that 'CPPSul' showed about 25 $\%$ susceptibility (Figure $2 b$ ) in the spring it showed high yields late in the summer in 2015, when the negative effect of springtime disease seems to 

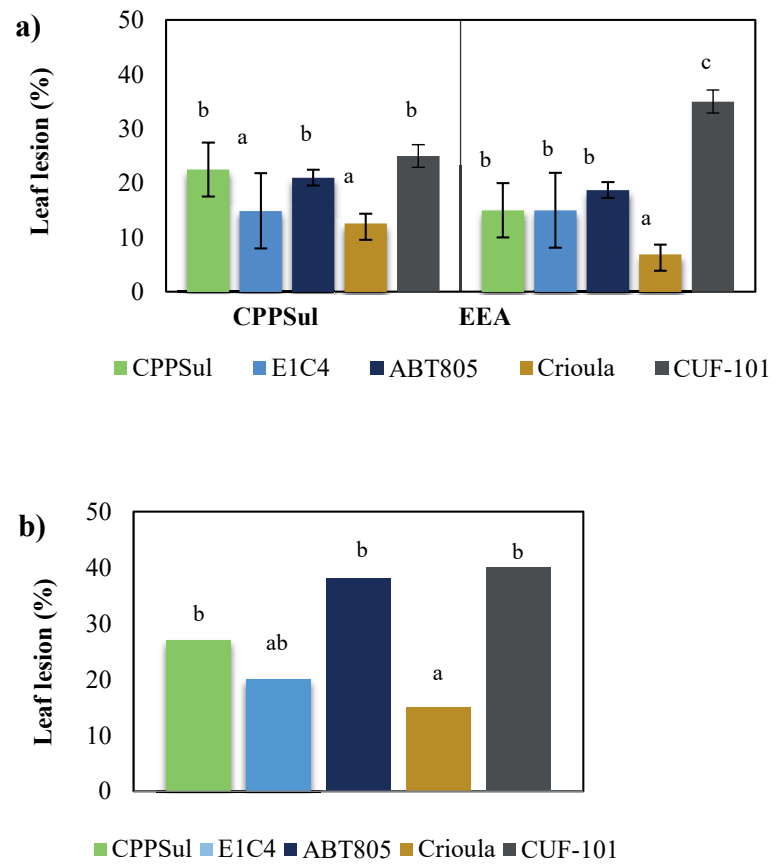

Figure 2 - a) Alfalfa leaf damage in experimental field trials 15 days after inoculation with Curvularia geniculata at the CPPSUL and EEA field sites; b) Alfalfa Leaf damage growth chamber experiments 15 days after inoculation with C. geniculata. Alfalfa genotypes: 'Crioula' (Brazilian, control commercial cultivar); ' $\mathrm{E}_{1} \mathrm{C}_{4}$ ' (Brazilian, grazing tolerant); 'CPPSul' (Brazilian, grazing tolerant); 'ABT-805' (US, grazing tolerant); and 'CUF-101' (US, west coast non-dormant). Site key: CPPSUL, Centro de Pesquisa de Pecuária dos Campos Sul-Brasileiros (Southern Brazilian Centre for Livestock Research) Bagé; EEA, Estação Experimental Agronômica (Agricultural Experimental Station) Eldorado do Sul. Bars show $95 \%$ confidence intervals. Bars with the same letters do not differ by the Tukey test $(\mathrm{p}<0.05)$.

have been compensated for (Table I). It would be interested to know the potential of this genotype if no disease had occurred early in its development.

When the damage caused a disease is quantified, measures are needed to mitigate the negative effects on crops. Such measures may include better disease control, pasture management and, most importantly, selection of genotypes with greater resistance, the latter being important in maintaining and improve the quality and productivity of Rio Grande do Sul pastures. Although it is not known whether $C$. geniculata has a large effect on the persistence of alfalfa in Brazil, it is likely that greater resistance of 'Crioula' is needed in relation to other diseases. Further studies are needed to investigate this hypothesis.

As far as we know, this is not only the first study in southern Brazil regarding the importance of foliar diseases in reducing forage yield but also the first to investigate the potential disease resistance and persistence of different genotypes. Our results are encouraging, in that they indicate the high degree of variability present in alfalfa genotypes, a factor that can be exploited to select genotypes resistant to C. geniculata, with 'Crioula' and ' $\mathrm{E}_{1} \mathrm{C}_{4}$ ' appearing to be especially useful resources for future work.

\section{FIELD EVALUATION OF FORAGE YIELD AND COMPETITION}

The field trials to assess competition and forage production showed that during the cold and rainy winter of 2014 (Figure 1) all three Brazilian genotypes 'Crioula' (2600 kg ha $\left.{ }^{-1}\right), \mathrm{E}_{1} \mathrm{C}_{4}$ ' $(2250 \mathrm{~kg}$ $\mathrm{ha}^{-1}$ ) and 'CPPSul' (2150 kg ha ${ }^{-1}$ genotypes (Table I) produced an adequate amount of dry forage, not differing statistically among themselves. Regarding the overall totals for all seasons combined, total leaf dry mass production was highest for 'Crioula' (12750 kg ha $\left.{ }^{-1}\right)$ and 'CPPSul' (12250 kg ha $\left.{ }^{-1}\right)$, lower for ' $\mathrm{E}_{1} \mathrm{C}_{4}$ ' $\left(5650 \mathrm{~kg} \mathrm{ha}^{-1}\right)$ and lowest for 'ABT-805' and 'CUF-101' (Table I). Stem dry matter showed the same tendency. Favourable rainfall occurred at the site in the spring and autumn of 2014 (Figure 1), during which the highest leaf dry matter values were seen with the 'Crioula' and 'CPPSul' genotypes (Table I). This is important because leaves are the most valuable nutritional component of alfalfa. In the first period evaluated, spring 2013, 'ABT-805' showed a reasonable initial production of leaf dry matter (900 kg ha $\left.{ }^{-1}\right)$, higher than 'CPPSul' (800 kg $\mathrm{ha}^{-1}$ ). However, with the establishment of invasive plants the production declined dramatically in 
TABLE I

Alfalfa leaf, stem and total dry matter yield $\left(\mathrm{kg} \mathrm{ha}^{-1}\right)$ for spring 2013, summer, autumn, winter and spring 2014 and summer 2015. The trials were carried out at the Agricultural Experimental Station (Estação Experimental Agronômica, EEA), Eldorado do Sul, Rio Grande do Sul, Brazil.

\begin{tabular}{|c|c|c|c|c|c|c|c|}
\hline \multirow[b]{8}{*}{ Genotype* } & \multicolumn{6}{|c|}{ Year and cuts (day and month) } & \multirow{7}{*}{$\begin{array}{l}\text { Overall totals } \\
\text { for all seasons } \\
\text { combined }\end{array}$} \\
\hline & & Summer & \multirow{3}{*}{$\begin{array}{l}\text { Autumn } \\
\mathbf{2 0 1 4} \\
25\end{array}$} & \multirow{2}{*}{$\begin{array}{l}\text { Winter } \\
2014\end{array}$} & \multirow{3}{*}{$\begin{array}{l}\text { Spring } \\
\mathbf{2 0 1 4} \\
14\end{array}$} & \multirow{3}{*}{ 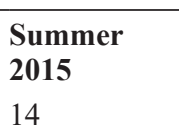 } & \\
\hline & 2013 & & & & & & \\
\hline & 22 & 20 & & & & & \\
\hline & November & January & April & June & November & January & \\
\hline & 10 & 10 & & 04 & 08 & & \\
\hline & December & February & & September & December & & \\
\hline & \multicolumn{6}{|c|}{ Leaf dry mass per season $\left(\mathrm{kg} \mathrm{ha}^{-1}\right)$} & $\begin{array}{l}\text { Total leaf dry mass } \\
\left(\mathrm{kg} \mathrm{ha}^{-1}\right)\end{array}$ \\
\hline ABT-805 & $900 \mathrm{Aa}$ & $700 \mathrm{Ab}$ & $750 \mathrm{Aa}$ & $900 \mathrm{Ab}$ & $1000 \mathrm{Ab}$ & $800 \mathrm{Aab}$ & 5050 \\
\hline CPPSul & $800 \mathrm{Ba}$ & $3350 \mathrm{Aa}$ & $1100 \mathrm{Ba}$ & $1300 \mathrm{ABab}$ & $2800 \mathrm{Aa}$ & $2900 \mathrm{Aa}$ & 12250 \\
\hline Crioula & $1150 \mathrm{Ba}$ & $2200 \mathrm{Aa}$ & $2200 \mathrm{Ba}$ & $2050 \mathrm{Aa}$ & $2900 \mathrm{Aa}$ & $2250 \mathrm{Aa}$ & 12750 \\
\hline CUF-101 & $400 \mathrm{Aa}$ & $150 \mathrm{Ab}$ & $550 \mathrm{Aa}$ & $900 \mathrm{Ab}$ & $200 \mathrm{Ab}$ & $350 \mathrm{Ab}$ & 2550 \\
\hline \multirow[t]{2}{*}{$\mathrm{E}_{1} \mathrm{C}_{4}$} & $750 \mathrm{ABa}$ & $700 \mathrm{ABb}$ & $800 \mathrm{ABa}$ & $1850 \mathrm{Aa}$ & $500 \mathrm{Bb}$ & $1050 \mathrm{ABab}$ & 5650 \\
\hline & \multicolumn{6}{|c|}{ Stem dry mass per season $\left(\mathrm{kg} \mathrm{ha}^{-1}\right)$} & $\begin{array}{l}\text { Total stem dry } \\
\text { mass }\left(\mathrm{kg} \mathrm{ha}^{-1}\right)\end{array}$ \\
\hline ABT-805 & $1050 \mathrm{Aa}$ & $800 \mathrm{Aa}$ & $450 \mathrm{ABa}$ & $250 \mathrm{Bb}$ & $450 \mathrm{Ba}$ & $800 \mathrm{Aab}$ & 3800 \\
\hline CPPSul & $400 \mathrm{Ba}$ & $900 \mathrm{Aa}$ & $550 \mathrm{ABa}$ & $850 \mathrm{Aa}$ & $550 \mathrm{ABa}$ & $1050 \mathrm{Aa}$ & 4300 \\
\hline Crioula & $600 \mathrm{Aa}$ & $750 \mathrm{Aa}$ & $800 \mathrm{Aa}$ & $550 \mathrm{Aab}$ & $900 \mathrm{Aa}$ & $500 \mathrm{Aab}$ & 4100 \\
\hline CUF-101 & $600 \mathrm{Aa}$ & $500 \mathrm{Aa}$ & $450 \mathrm{Aa}$ & $200 \mathrm{Ab}$ & $600 \mathrm{Aa}$ & $250 \mathrm{Ab}$ & 2600 \\
\hline \multirow[t]{2}{*}{$\mathrm{E}_{1} \mathrm{C}_{4}$} & $600 \mathrm{Aa}$ & 700Aa & 350Aa & $400 \mathrm{Aab}$ & 450Aa & 700Aab & 3200 \\
\hline & \multicolumn{6}{|c|}{ Total $\left(\right.$ leaf + stem) dry mass per season $\left(\mathrm{kg} \mathrm{ha}^{-1}\right)$} & $\begin{array}{l}\text { Total stem + leaf } \\
\text { dry mass }\left(\mathrm{kg} \mathrm{ha}^{-1}\right)\end{array}$ \\
\hline ABT-805 & $1450 \mathrm{Aa}$ & $1500 \mathrm{Abc}$ & $1150 \mathrm{Aa}$ & $700 \mathrm{Ab}$ & $950 \mathrm{Ab}$ & $1600 \mathrm{Aab}$ & 7350 \\
\hline CPPSul & $1250 \mathrm{Ba}$ & $4250 \mathrm{Aa}$ & $1600 \mathrm{Ba}$ & $2150 \mathrm{ABa}$ & $3350 \mathrm{Aa}$ & 4000Aa & 16600 \\
\hline Crioula & $1750 \mathrm{Ba}$ & $2950 \mathrm{ABab}$ & $1900 \mathrm{Ba}$ & $2600 \mathrm{ABa}$ & $3800 \mathrm{Aa}$ & $2750 \mathrm{ABa}$ & 15750 \\
\hline CUF-101 & $1000 \mathrm{Aa}$ & $650 \mathrm{Ac}$ & $1000 \mathrm{Aa}$ & $650 \mathrm{Ab}$ & $800 \mathrm{Ab}$ & $650 \mathrm{Ac}$ & 4750 \\
\hline $\mathrm{E}_{1} \mathrm{C}_{4}$ & $1250 \mathrm{Aa}$ & $1400 \mathrm{Abc}$ & $1150 \mathrm{Aa}$ & $2250 \mathrm{Aa}$ & $950 \mathrm{Ab}$ & $1750 \mathrm{Aab}$ & 8750 \\
\hline
\end{tabular}

Means followed by the same upper-case letters in the same line and the same lower-case letters in the same column do not differ significantly by the Tukey test $(\mathrm{p}<0.05)$.

*Key: 'Crioula' (Brazilian, control commercial genotype); ' $\mathrm{E}_{1} \mathrm{C}_{4}$ ' and 'CPPSul' (both Brazilian grazing tolerant genotypes); 'ABT805 ' (US, grazing tolerant); 'CUF-101' (US west coast non-dormant).

comparison with the other genotypes (Figure 1, Table I).

The genotypes with the highest production of overall total dry matter were 'CPPSul' $(16,600$ $\left.\mathrm{kg} \mathrm{ha}^{-1}\right)$ and Crioula $\left(15,750 \mathrm{~kg} \mathrm{ha}^{-1}\right)$, which were statistically similar. Not only this, but these two genotypes stand out for presenting the highest total dry matter production in the spring and summer of 2014, even when inoculated with $C$. geniculata
(Table I). A study in Sertãozinho, São Paulo, Brazil, involving 35 alfalfa genotypes showed that 'Crioula' produced the highest forage yields (Ruggieri et al. 2001). This supports our results, which show that there was no statistically significant difference between 'Crioula' and 'CPPSul', both of which produced the highest forage yields, although 'CPPSul' is known to be less resistant to folia diseases. The identification of cultivars that present 
a wide adaptability of dry matter production, in the cuts made throughout the year, is of great interest (Ferreira et al. 2004).

The low total dry matter production was associated with the high incidence of invasive plants present in the alfalfa crop, due to the fact that no chemical or mechanical weed control was used. North America annual grasslands heavily infested with medusahead (Taeniatherum caput-medusae (L.) Nevski) have been reported to show reductions in livestock carrying capacity of as much as $75 \%$ to $80 \%$ (Major et al. 1960, Hironaka 1961, George 1992), reinforcing the need to select forage plants with higher competitiveness. In our research, the correlation between total dry matter and invasive plants was negative and significant $(\mathrm{p}<0.005)$. The 'Crioula' cultivar seemed to be very competitive, showing only $10 \%$ of invasive plants after ten months of evaluation. In all evaluations, the Brazilian cultivar, selected for grazing tolerance, showed a higher incidence of invasive plants (minimum, 15\%) than the 'Crioula' cultivar. This explains the low forage total dry matter value of ' $\mathrm{E}_{1} \mathrm{C}_{4}$ ' seen in most of the evaluations (Figure 3). This correlation was also observed for the US cultivar 'CUF-101', which also demonstrated high incidence of invasive plants and low forage production, probably because it is not well adapted to conditions in southern Brazil. In relation to seasonal variation, we observed a higher occurrence of invasive plants (Figure 3) during the summer months $(\mathrm{p}<0.005)$.

In our future selection experiments, we intend to use plants showing some level of disease resistance coupled with good agronomic traits. In the study described in the present paper, we observed intermediate results with genotype ' $\mathrm{E}_{1} \mathrm{C}_{4}$ ' and the more promising results for the 'Crioula' and 'CPPSul' genotypes. These will be the plants which we will cross to produce $\mathrm{F}_{1}$ seeds which will be assessed for their potential to produce better genotypes.

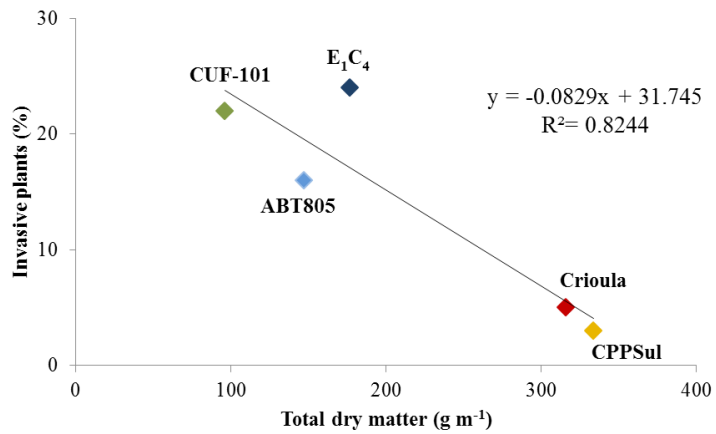

Figure 3 - Relationship between invasive plants and total dry matter of alfalfa genotypes in the field at the Agricultural Experimental Station (Estação Experimental Agronômica, EEA), Eldorado do Sul, Rio Grande do Sul, Brazil. Alfalfa genotypes: 'Crioula' (Brazilian, control commercial genotype); ' $\mathrm{E}_{1} \mathrm{C}_{4}$ ' (Brazilian, grazing tolerant); 'CPPSul' (Brazilian, grazing tolerant); 'ABT-805' (US, grazing tolerant); and 'CUF-101' (US, west coast non-dormant).

Further selection experiments will be performed by our group using plants showing some level of disease resistance coupled with good agronomic traits. In the study described in the present paper, intermediate results were observed with genotype ' $\mathrm{E}_{1} \mathrm{C}_{4}$ ' and the more promising results for the 'Crioula' and 'CPPSul' genotypes. These plants will be crossed to produce $F_{1}$ seeds, which will be assessed for their potential to produce better genotypes.

It has been reported that in the Lavras-UFLA area in the south of the Brazilian state of Minas Gerais spot disease caused by Leptosphaerulina briosiana occurred with greater frequency during the coldest parts of the year (Pereira et al. 2003). It is interesting to note that the 'Crioula' genotype was the most resistant, with a mean annual severity of only $0.8 \%$. This might be a fruitful area for further research.

Our results may have relevance to agriculturalists and ranchers not only in Rio Grande do Sul but also in other parts of the globe where alfalfa is planted and where economic pressures necessitate ever increasing productivity gains. 


\section{REFERENCES}

ANUALPEC. 2010. Anuário da pecuária brasileira. São Paulo: Instituto FNP, $360 \mathrm{p}$.

BAILEY CC AND MUCHOVEJ JJ. 2001. Seed pathology of native scrub grasses. Proceedings of the $114^{\text {th }}$ Annual Meeting of the Florida State Horticultural Society, Stuart, Florida, 114: 236-237.

BARCELLOS AO, RAMOS AKB, VILELA L AND JUNIOR GBM. 2008. Sustentabilidade da produção animal baseada em pastagens consorciadas e no emprego de leguminosas exclusivas, na forma de banco de proteína, nos trópicos brasileiros. R Bras Zootec 37: 51-67.

BARNES DK. 1991. Minnesota fall dormancy and its relationship to winter injury. In: Proceedings of the $21^{\text {st }}$ National Alfalfa Symposium, Rochester, MN. Cert. Alfalfa Seed Council, Inc., Davis, CA, p. 14-16.

BARNETT HJ AND HUNTER BB. 1999. Illustrated genera of imperfect fungi. $4^{\text {th }}$ ed., Minnesota: American Phytopathology Society, $218 \mathrm{p}$.

BERGAMASCHI H, GUADAGNIN MR, CARDOSO LS AND SILVA MIG. 2003. Clima da Estação Experimental da UFRGS (e região de abrangência). Porto Alegre: UFRGS, $77 \mathrm{p}$.

BEUSELINCK PR, BOUTON JH, LAMP WO, MATCHES AG, MCCASLIN MH, NELSON CJ, RHODES LH, SHEAFFER CC AND VOLENEC JJ. 1994. Improving legume persistence in forage crop systems. J Prod Agric 7(3): 311-322.

BOUTON JH. 2012. Breeding lucerne for persistence. Crop and Pasture Science 63(2): 95-106.

BUHLER DD, NETZER DA, RIEMENSCHNEIDER DE AND HARTZLER RG. 1998. Weed management in short rotation poplar and herbaceous perennial crops grown for biofuel production. Biomass Bioenerg 14(4): 385-394.

BURDON JJ. 1980. Variation in disease resistance within a population of Trifolium Repens. J Ecol 68: 737-744.

CHAKRABORTY S, LEATH KT, SKIPP RA, PEDERSON GA, BRAY RA, LATCH GCM AND NUTTER FW. 1996. Pasture and Forage Crop Pathology. ASA, CSSA, and SSSA, Madison, WI, $653 \mathrm{p}$.

COSTA FP. 2010. Natureza econômica e impacto das pastagens no custo de produção da pecuária de corte. Campo Grande: Embrapa Gado de Corte, Document, 181, 2 p.

DOYLE JJ AND DOYLE JL. 1987. A rapid DNA isolation procedure for small quantities of fresh leaf tissue. Phytochem Bull 19(1987): 11-15.

ELGIN JR, WELTY RE AND GILCHRITI DB. 1988. Breeding for disease and nematode resistance. In: alfalfa and alfalfa improvement. Agronomy 29: 827-858.

EMBRAPA - EMPRESA BRASILEIRA DE PESQUISA AGROPECUÁRIA. 2013. Sistema Brasileiro de Classificação de Solos. $3^{\mathrm{a}}$ ed., 353 p.
FALLOON RE. 1976. Curvularia trifolii as a high-temperature turfgrass pathogen. New Zealand Journal of Agricultural Research, 19.

FAO - FOOD AND AGRICULTURE ORGANIZATION OF THE UNITED NATIONS. 2010. Accessed: Sep. 15, 2010.

FAO - FOOD AND AGRICULTURE ORGANIZATION OF THE UNITED NATIONS. 2011. How to feed the world in 2050. Available at: http://www.fao.org/fileadmin/ templates/wsfs/docs/expert_paper/How_to_Feed_the World_in_2050.pdf Accessed: Dec. 12, 2016.

FORESIGHT. 2011. The future of food and farming. Final project report. London: The Government Office for Science. Available at: https://www.gov.uk/government/ uploads/system/uploads/attachment_data/file/28832 9/11-546-future-of-food-and-farming-report.pdf Accessed: Dec. 12, 2016.

FEE - FUNDAÇÃO DE ECONOMIA E ESTATÍSTICA DO GOVERNO DO ESTADO DO RIO GRANDE DO SUL. 2015. Characterísticas da agropecuária do RS. Available at: http://www.fee.rs.gov.br/sinteseilustrada/ caracteristicasda-agropecuaria-do-rs/. Accessed: Dec. 12, 2016.

FERREIRA RP, BOTREL MA, RUGGIERE AC, PEREIRA AV, COELHO ADF, LÉDO FJS AND CRUZ CD. 2004. Adaptabilidade e estabilidade de cultivares de alfafa em relação a diferentes épocas de corte. Santa Maria. Ciência Rural 34: 265-269.

GEORGE MR. 1992. Ecology and management of medusahead. Range Science Report. Dept. Agronomy and Range Science. Agr Exp Stat Series 32: 3.

GOSSEN BD. 1994. Field Response of Alfalfa to Harvest Frequency, Cultivar, Crown Pathogens, and Soil Fertility: II. Crown Rot 86(1): 88-93.

GRAY FA AND FERNANDEZ JA. 1987. Efficacy of chlorothalonil for control of spring black stem and common leaf spot of alfalfa. Plant Disease 71: 752-755.

HIRONAKA M. 1961. The relative rate of root development of cheatgrass and medusahead. J Range Manage 14(5): 463-467.

HODGES CF. 1972. Interaction of culture age and temperature on germination and growth of Curvularia geniculata and on virulence. Can J Bot 50(11): 2093-2096.

JIN MZ. 1989. Preliminary study of discoloured rice grains caused by Curvularia. Acta Phytopathol Sinica 19(1): 2126.

JUNG HG, SHEAFFER CC, BARNES DK AND HALGERSON JL. 1997. Forage Quality Variation in the U.S. Alfalfa Core Collection. Crop Sci 37: 1361-1366.

KHASANOV BA, SHAVARINA ZA, VYPRITSKAYA AA AND TERENT'EV DV. 1990. Characteristics of the fungi from the genus Curvularia Boedijn and their pathogenicity to cereals. USSR. Mikol Fitopatol 24(2): 165-173.

KIM JC, CHOI GJ, KIM HT, KIM HJ AND CHO KY. 2000. Pathogenicity and Pyrenocine Production of Curvularia 
inaequalis Isolated from Zoysia Grass. Plant disease 84(6): 305-606.

LIU YJ, WHELEN S AND HALL BD. 1999. Phylogenetic relationships among ascomycetes: evidence from an RNA polymerase II subunit. Mol Biol Evol 16: 1799-1808.

MAJOR J, MCKELLCMAND BERRY L. 1960. Improvement of medusahead infested rangeland. California Agricultural Experiment Station, Extension Service. Division of Agricultural Sciences, University of California, Berkeley.

MALLMANN G, VERZIGNASSI JR, FERNANDES CD, SANTOS JM, VECHIATO MH, INÁCIO CA, BATISTA MV AND QUEIROZ CA. 2013. Fungos e nematoides associados a sementes de forrageiras tropicais. Summa Phytopathol 39: 201-203.

MICHAUD R, LEHMAN WF AND RUMBAUCH MD. 1988. World distribution and historical development. In: Hanson AA, Barnes DK, Hill RR, Alfalfa and Alfalfa Improvement. Agronomy Monograph 29: 25-91.

NELSON SC AND CAMPBELL CL. 1993. Disease progress, defoliation, and spatial pattern in a multiple-pathogen disease complex on white clover. Phytopathol 83: 419-429.

NELSON RR. 1964. The perfect stage of Curvularia geniculata. Mycologia 56: 777-779.

PEREIRA RC, EVANGELISTA AR, SOUZA PE, SILVA AC AND MUNIZ JA. 2003. Doenças Foliares da Alfafa (Medicago sativa L.), em Lavras, Minas Gerais. Revista Bras Zootec 32(6): 1287-1296.

PORTO MDM. 1988. Problemas Fitoppatológicos. In: Nuernberg NJ, Milan PA and Silveira CAM (Eds), Manual de produção de alfafa. Florianópolis: EMPASC, p. 345349.

POZZA EA AND SOUZA PE. 1994. Ocorrência de Doenças em Alfafa (Medicago sativa L.) na região de Lavras, MG. Ciência e Prática 18(2): 186-188.

PRATT RG. 2005. Variation in occurrence of dematiaceous hyphomycetes on forage bermudagrass over years, sampling times, and locations. Phytopathol 95(10): 11831190.

ROGERSON CT. 1956. Diseases of grasses in Kansas: 195355. J Plant Disease Report 40(5): 388-397.

ROESCH LFW, VIEIRA FCB, PEREIRA VA, SCHÜNEMANN AL, TEIXEIRA IF AND SENNA AJT. 2009. The Brazilian Pampa: A Fragile Biome. Diversity 1: $182-198$.

RUGGIERI AC, SHIMIDEK A, BOMBOWATO EM AND FIGUEIREDO LA. 2001. Produção de 35 cultivares de alfafa com quatro anos de cultivos em Sertãozinho, SP. In: Reunião anual da Sociedade Brasileira de Zootecnia, 2001. 38., Botucatu, Anais... Botucatu, SBZ, 38 (CD-ROM).

SHEAFFER CC, BARNES DK, WARNES DD, LUESCHEN WE, FORD HJ AND SWANSON DR. 1992. Seeding-year cutting affects winter survival and its association with fall growth score in alfalfa. Crop Science 32: 225-231.
SDPI - SECRETARIA DE DESENVOLVIMENTO E PROMOÇÃO DO INVESTIMENTO DO GOVERNO DO ESTADO DO RIO GRANDE DO SUL. 2013. Programa Sectorial Agroindústria Carne Bovina. Revisão. 2013. Available at: http://www.sct.rs.gov.br/upload/2013110111 5431[revisao_2013]_[espanhol]_agroindustria__carne bovina_[red].pdf. Accessed: Dec. 12, 2016.

SKIPP RA AND HAMPTON JG. 1996. Fungal and bacterial diseases of pasture plants in New Zealand. In: Chakraborty S, Leath KT, Skipp RA, Pederson GA, Bray RA, Latch GCM and Nutter FW (Eds), Pasture and Forage Crop Pathology. ASA, CSSA, SSSA. Madison, Wisconsin.

SMITH SR, BOUTON JH AND HOVELAND CS. 1989. Alfalfa persistence and Regrowth Potential under Continuous Grazing. Agron J 81(6): 960-965.

STRECK EV, KAMPF N, DALMOLIN RSD, KLAMT E, NASCIMENTO PC, SCHNEIDER P, GIASSON E AND PINTO LFS. 2008. Solos do Rio Grande do Sul. 2a ed., Porto Alegre: EMATER/RS, p. 222.

SUNG GH, SUNG JM, HYWEL-JONES NL AND SPATAFORA JW. 2007. A multi-gene phylogeny of Clavicipitaceae (Ascomycota, Fungi): Identification of localized incongruence using a combinational bootstrap approach. Mol Phylo Evol 44: 1204-1223.

THAL WM AND CAMPBELL CL. 1987. Assessment of resistance to leaf diseases among alfalfa cultivars in North Carolina fields. Phytopathol 77(6): 964-968.

THIRUMALACHAR MJ AND NARASIMHAN MJ. 1953. Notes on Some Mycological Methods. Mycologi 45(3): 461-468.

USDA - UNITED STATED DEPARTMENT OF AGRICULTURE. 1999. Soil Taxonomy. A Basic System of Soil Classification for Making and Interpreting Soil Surveys, p. 1-871.

USDA - UNITED STATED DEPARTMENT OF AGRICULTURE. 2012. Livestock and poultry: world markets and trade. Available at: http://www.thefarmsite. com/reports/contents/lipoct12.pdf. Accessed: Dec. 12, 2016.

USDA - UNITED STATED DEPARTMENT OF AGRICULTURE. 2016. Livestock and poultry: world markets and trade. Available at https://apps.fas.usda.gov/ psdonline/circulars/livestock_poultry.pdf Accessed: Dec. 17, 2016.

WHITE TJ, BRUNS T, LEE S AND TAYLOR JW. 1990. Amplification and direct sequencing of fungal ribosomal RNA genes for phylogenetics (p. 315-322) In: Innis MA, Gelfand DH, Sninsky JJ and White TJ (Eds), PCR Protocols: A Guide to Methods and Applications, Academic Press Inc., New York.

WILLIAMS RE, ALLRED BW, DENIO RM AND JUNIOR HAP. 1968. Conservation, Development, and Use of the World's Rangelands. J Range Manage 21(6): 355-360. 